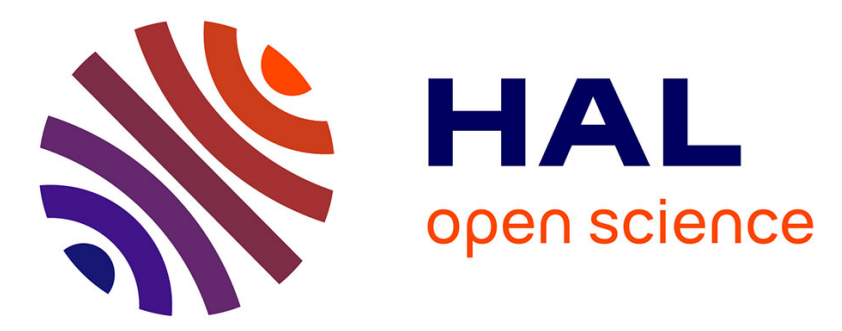

\title{
New flat wasps from mid-Cretaceous Burmese amber deposits highlight the bethylid antiquity and paleobiogeography (Hymenoptera: Chrysidoidea)
}

\author{
Corentin Jouault, Vincent Perrichot, André Nel
}

\section{To cite this version:}

Corentin Jouault, Vincent Perrichot, André Nel. New flat wasps from mid-Cretaceous Burmese amber deposits highlight the bethylid antiquity and paleobiogeography (Hymenoptera: Chrysidoidea). Cretaceous Research, 2021, 123, pp.104772. 10.1016/j.cretres.2021.104772 . insu-03132639

HAL Id: insu-03132639

https://hal-insu.archives-ouvertes.fr/insu-03132639

Submitted on 5 Feb 2021

HAL is a multi-disciplinary open access archive for the deposit and dissemination of scientific research documents, whether they are published or not. The documents may come from teaching and research institutions in France or abroad, or from public or private research centers.
L'archive ouverte pluridisciplinaire HAL, est destinée au dépôt et à la diffusion de documents scientifiques de niveau recherche, publiés ou non, émanant des établissements d'enseignement et de recherche français ou étrangers, des laboratoires publics ou privés. 


\section{Journal Pre-proof}

New flat wasps from mid-Cretaceous Burmese amber deposits highlight the bethylid antiquity and paleobiogeography (Hymenoptera: Chrysidoidea)

Corentin Jouault, Vincent Perrichot, André Nel

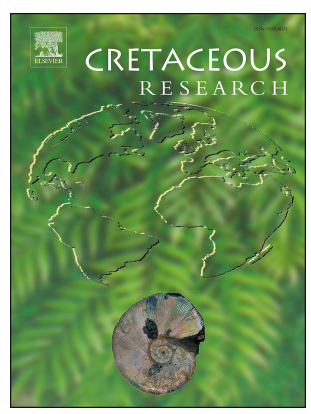

PII:

S0195-6671(21)00019-7

DOI: https://doi.org/10.1016/j.cretres.2021.104772

Reference: $\quad$ YCRES 104772

To appear in: Cretaceous Research

Received Date: 17 July 2020

Revised Date: 18 November 2020

Accepted Date: 26 January 2021

Please cite this article as: Jouault, C., Perrichot, V., Nel, A., New flat wasps from mid-Cretaceous Burmese amber deposits highlight the bethylid antiquity and paleobiogeography (Hymenoptera: Chrysidoidea), Cretaceous Research, https://doi.org/10.1016/j.cretres.2021.104772.

This is a PDF file of an article that has undergone enhancements after acceptance, such as the addition of a cover page and metadata, and formatting for readability, but it is not yet the definitive version of record. This version will undergo additional copyediting, typesetting and review before it is published in its final form, but we are providing this version to give early visibility of the article. Please note that, during the production process, errors may be discovered which could affect the content, and all legal disclaimers that apply to the journal pertain.

() 2021 Elsevier Ltd. All rights reserved. 
Toumal Pre-proof

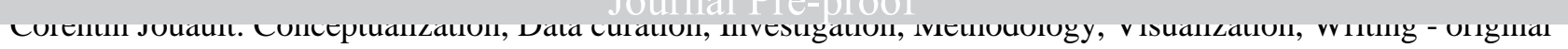
draft, Writing - review \& editing. Vincent Perrichot: Data curation, Investigation, Writing - original draft, Writing - review \& editing. André Nel: Supervision, Data curation, Investigation, Writing - original draft, Writing - review $\&$ editing. 
Ivew llal wasps irom mia-cretaceous surmese amoer aeposits nignilgnı ine

2 bethylid antiquity and paleobiogeography (Hymenoptera: Chrysidoidea)

4 Corentin Jouault $^{\mathrm{a}}{ }^{*}$, Vincent Perrichot $^{\mathrm{a}}$, André Nel ${ }^{\mathrm{b}}$

6 a Univ. Rennes, CNRS, Géosciences Rennes, UMR 6118, 35000 Rennes, France E-mail:

7 jouaultc0@gmail.com / vincent.perrichot@univ-rennes1.fr

$8{ }^{b}$ Institut de Systématique, Évolution, Biodiversité (ISYEB) - UMR 7205 - Muséum national

9 d'Histoire naturelle, CNRS, SU, EPHE, Université des Antilles, CP50, 57 rue Cuvier F-75005 Par-

10 is, France. E-mail: anel@mnhn.fr

11 *Corresponding author: jouaultc0@gmail.com

\section{Abstract}

14 Examination of Hkamti and Tanai Burmese ambers reveals two new genera and species of $15 †$ †ancepyrinae: Protopyris myanmarensis Jouault \& Nel gen. et sp. nov. and Burmapyris azevedoi 16 Jouault, Perrichot \& Nel gen. et sp. nov. Protopyris Jouault \& Nel gen. nov. is the first Bethylidae 17 described from amber of the Hkamti deposit (lower Albian, mid-Cretaceous) in Myanmar. These 18 specimens provide useful clues to understand the paleobiogeographic evolution of the $19 \dagger$ Lancepyrinae, since they are only predated by genera described from Lebanese and Spanish amber.

20 These new taxa suggest a major paleobiogeographic scenario, since Burmese amber was probably

21 produced on an island that separated from Gondwana during the Late Jurassic to Early Cretaceous.

22 It thus suggests a possible earlier origin for the $\dagger$ Lancepyrinae, and thereby for the Bethylidae, in

23 the Late Jurassic to earliest Cretaceous.

25 Key words. Hkamti amber, Bethylidae, $\nmid$ Lancepyrinae, paleobiogeography, Abian 
28 The $†$ Lancepyrinae are a small extinct bethylid subfamily, originally described from Barremian

29 Cretaceous Lebanese amber (Azevedo and Azar, 2012). Members can be easily distinguished from

30 related taxa mainly by having fore wing venation with an unusual combination of closed lanceolate

31 cell 2R1, tubular and well-pigmented vein Rs+M, and angled vein Rs\&M (Azevedo and Azar 2012).

32 Later, this work was supplemented by the additions of Ortega and Engel (2013) and Engel et al.

33 (2016), with descriptions of further lancepyrine genera and species, challenging the constant pres-

34 ence of a tubular Rs+M vein. †Lancepyrinae were hitherto known only by five species from Leba-

35 nese, Spanish, and Taimyr amber (Evans, 1973; Azevedo and Azar, 2012; Ortega-Blanco and Engel,

36 2013; Engel et al., 2016), but remained unknown from the Burmese amber biota. As for the other

37 bethylid fossil subfamilies, we do not have a record of behavior or clue to understand

$38 \dagger$ Lancepyrinae biology (Azevedo et al., 2018).

39 Recently, two phylogenies have been proposed to investigate the relationships between

40 Bethylidae subfamilies (Jouault et al., 2020a; Colombo et al., 2020). However, if their results do not

41 record $\nmid$ Lancepyrinae at exactly the same position, both recover them as an early diverging lineage

42 among Bethylidae. In Jouault et al. (2020a: fig 6), they fall as a part of separate radiation

43 (†Lancepyrinae $+\nmid$ Protopristocerinae) sister group of the clade $($ Mesitiinae + Pristocerinae +

44 Epyrinae + Scleroderminae); while Colombo et al. (2020: fig 1B) recorded them as sister group to

45 the clade (Mesitiinae + †Elektroepyrinae + Pristocerinae + Epyrinae + Scleroderminae +

$46 \dagger$ Protopristocerinae). It is therefore probable that new phylogenies will be necessary to clarify this

47 placement, above all a molecular phylogeny updating the results of Carr et al. (2010).

48 Herein, we describe the first records of $†$ Lancepyrinae from two Cretaceous Burmese amber depos-

49 its, and we discuss their placement and the implication on the paleobiogeographic history of the 50 subfamily.

\section{Material and methods}




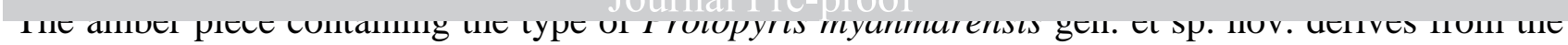

54 deposits of Hkamti site (about $80 \mathrm{~km}$ southwest of the Angbamo site), Hkamti District, Sagaing

55 Region, Myanmar, see detailed map in Zheng et al. (2018: supplementary figure 2) or in Xing and

56 Qiu, (2020: fig. 1). Zircon U-Pb analyses established an early Albian age (109.7 $\pm 0.4 \mathrm{Ma})$ for

Hkamti amber, based on zircon analyses of clastic deposits at the surface (Xing \& Qiu, 2020). The paleobiota from this deposit is almost unknown, with only one ostracod and one Diapriidae described to date (Xing et al., 2018; Jouault et al., 2020b). The amber piece containing the type of

60 Burmapyris azevedoi gen. et sp. nov. derives from the deposits of Noije Bum in the Hukawng Valley $\left(26^{\circ} 29^{\prime} \mathrm{N}, 96^{\circ} 35^{\prime} \mathrm{E}\right)$, Kachin State, northern Myanmar (see detailed map in Grimaldi and Ross, 2017: fig. 2). Radiometric data established an earliest Cenomanian age (98.79 $\pm 0.62 \mathrm{Ma})$ for Kachin amber, based on zircons from volcanic clasts found within the amber-bearing sediments (Shi et al., 2012). Some ammonites found in the amber-bearing bed and within amber corroborate a late Albian-early Cenomanian age (Cruickshank and Ko, 2003; Yu et al., 2019).

The specimens were examined and photographed using a Leica MZ APO stereomicroscope equipped with a Canon EOS 5D Mark II camera. All images are digitally stacked photomicrographic composites of several individual focal planes, which were obtained using HeliconFocus 6.7. The figures were composed with Adobe Illustrator CC 2019 and Adobe Photoshop CS19 software. The specimens are housed in the amber collection of the Geological Department and Museum (IGR) of the University of Rennes, France. We follow the nomenclature, classification, and terminology for morphological features of the body and wing venation of Azevedo et al. (2018).

Main measurements and abbreviations used are as follows: length of fore wing (LFW); length of head, mandibles excluded (LH); width of head (WH); width of frons (WF); height of eye (HE); length of eye (LE); ocello-ocular line (OOL); width of ocellar triangle (WOT); diameter of 


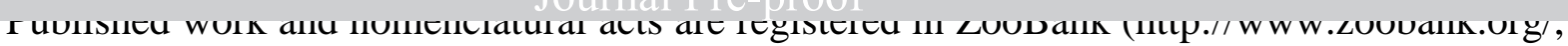

79 last access: 18 November 2020), with the following LSID (reference):

80 urn:lsid:zoobank.org:pub:42C094B2-B116-4F29-B118-8724D288FAE0

\section{Systematic paleontology}

83 Class Insecta Linnaeus, 1758

84 Order Hymenoptera Linnaeus, 1758

85 Superfamily Chrysidoidea Latreille, 1802

86 Family Bethylidae Haliday, 1839

87 Subfamily $\dagger$ Lancepyrinae Azevedo and Azar, 2012

89 Genus Protopyris gen. nov. Jouault \& Nel

90 Figs $1-2$

91 urn:1sid:zoobank.org:act:8C12080A-83F2-48D3-AC6D-7C92DA4C6710

93 Type species. Protopyris myanmarensis sp. nov. Jouault \& Nel

94 Etymology. The genus name is a combination of the Greek «prôtos » meaning 'primitive' and the

95 generic name Epyris, commonly used as a stem for many bethylid genera. Gender masculine.

96 Diagnosis. Body depressed; mandibles dentate with four(?) teeth along masticatory margin and one

97 long apical tooth; clypeus reduced, not projecting; antennae with 11 flagellomeres; scape less than 98 twice as long as pedicel; notauli conspicuous; fore wing venation developed, with cells $\mathrm{C}, \mathrm{R}, 1 \mathrm{Cu}$, $991 \mathrm{M}$, and 2R1 delimited by tubular veins; $\mathrm{M}$ and cu-a veins aligned; $2 \mathrm{Cu}$ not clearly delimited; $2 \mathrm{R} 1$ 100 opened at apex; pterostigma narrow, elongate; propodeum rectangular and not spinose; legs with 101 slightly enlarged femora. 
Holotype: Specimen identifier IGR.BU-015 (a nearly complete specimen, with right antenna destroyed, in a rectangular piece of amber measuring $5 \times 4 \times 1.5 \mathrm{~mm})$.

Etymology. Named after the originating country of the amber piece, Myanmar. The specific epithet is to be treated as an adjective in the genitive case.

110 Locality and horizon. Hkamti site, Hkamti District, Sagaing Region, Myanmar; lower Albian (ca. $111110 \mathrm{Ma})$, mid-Cretaceous.

112 Diagnosis. As for the genus.

113 Description. Sex unknown; body ca. $2.10 \mathrm{~mm}$ long, depressed, almost smooth and not strongly fo-

114 veolate; wings clear, setose, LFW $1.25 \mathrm{~mm}$. LH $0.50 \mathrm{~mm}$; WH $0.53 \mathrm{~mm}$; WF $0.31 \mathrm{~mm}$; LE 0.25

$115 \mathrm{~mm}$; OOL $0.15 \mathrm{~mm}$; WOT ca. $0.12 \mathrm{~mm}$; DAO $0.03 \mathrm{~mm}$; VOL $0.11 \mathrm{~mm}$. Head sub-quadrate, not 116 pubescent, with small dorsal median depression, finely punctate but not sculptured; mandible pro117 jecting forward, ca. $0.12 \mathrm{~mm}$ long, dentate, apparently with four equal, sharp, small teeth along 118 masticatory margin and one longer apical tooth; only two maxillary palpomeres visible (but certain119 ly more are present); flagellomeres with cylindrical cross-section; measurable antennomere lengths 120 (in mm) scape $0.11 \mathrm{~mm}$, pedicel $0.07 \mathrm{~mm}, \mathrm{~F} 1 \mathrm{ca} .0 .03 \mathrm{~mm}, \mathrm{~F} 2 \mathrm{ca} .0 .03 \mathrm{~mm}, \mathrm{~F} 30.05 \mathrm{~mm}, \mathrm{~F} 4$ to F10 121 sub-equal to equal ca. $0.06 \mathrm{~mm}$ (all flagellomeres compressed due to preservation, thereby useful 122 width measurements not provided); occipital carina slightly marked; posterior head margin nearly 123 straight with small median concavity; compound eye without microsetae, closer to mandibular in124 sertion than posterior to head margin; ocellar triangle nearly equilateral, with two posterior ocelli 125 slightly more distant from each other than from anterior.

126 Mesosoma with dorsum smooth, not roughly sculptured; femora slightly thickened, tibia thin, tarsal 127 claws simple; tibial spur formula 1-2-2; arolium present; notauli well-marked, posteriorly conver128 gent; parapsidal furrows weak; metanotum developed medially and overlapping mesoscutellum 129 posteriorly; metapectal-propodeal complex rectangular, not foveolate, with marginal carinae and no 


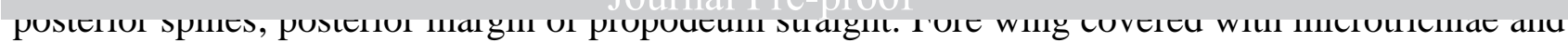

131 bordered with small microtrichiae; elongated with apical margin gently rounded; anterior border not angularly incurved anterior to pterostigma; veins $\mathrm{C}, \mathrm{Sc}+\mathrm{R}, \mathrm{A}, \mathrm{R} 1, \mathrm{Rs}, \mathrm{Rs}+\mathrm{M}, 2 \mathrm{r}-\mathrm{rs} \& \mathrm{Rs}, \mathrm{M}+\mathrm{Cu}, \mathrm{M}$, cu-a, $\mathrm{Cu}$ and cells $\mathrm{C}, \mathrm{R}, 1 \mathrm{Cu}, 1 \mathrm{M}$ and $2 \mathrm{R} 1$ present; $\mathrm{M}$ and cu-a veins aligned; cell $2 \mathrm{Cu}$ open, virtually enclosed by spectral vein; cell $2 \mathrm{R} 1$ distally opened; Rs+M prolonged as a spectral vein originating from $1 \mathrm{M}$ at level of pterostigma base; pterostigma long and narrow; prestigmal abscissa of R1 conspicuous. Hind wing with only veins $\mathrm{C}$ and $\mathrm{Sc}+\mathrm{R}$, hamuli uncountable.

Metasoma with short petiole; six tergites present, T1 reduced, T2 enlarged, all tergites convex, partly covering sternites; sting not preserved (apical part of metasoma destroyed); length of clearly visible tergites: T1 $0.26 \mathrm{~mm}$, T2 $0.15 \mathrm{~mm}$, T3 ca. $0.15 \mathrm{~mm}$, more distal tergites impossible to measure

140 because of bent metasoma.

142 Genus Burmapyris gen. nov. Jouault, Perrichot \& Nel

143 Figs 3-4

144 urn:lsid:zoobank.org:act:A627B4D5-35BB-48F5-B198-A2721DDB01D1

145 Type species. Burmapyris azevedoi Jouault, Perrichot \& Nel sp. nov.

146 Etymology. The generic epithet is a combination of 'Burma' referring to Burmese amber and the

147 generic name Epyris, commonly used as a suffix for many bethylid genera. Gender masculine.

148 Diagnosis. Female (sting visible) with body weakly depressed; mandibles heavily dentate with

149 five(?) sharp teeth along masticatory margin, with apical tooth longer and stouter; clypeus triangular 150 and slightly projecting; antennae stout, with 11 flagellomeres; scape nearly twice as long as pedicel; 151 notauli conspicuous; fore wing venation developed, with cells $\mathrm{C}, \mathrm{R}, 1 \mathrm{Cu}$, and $2 \mathrm{R} 1$ delimited by 152 tubular veins; $\mathrm{M}$ and cu-a veins aligned; pre- and post-stigmal R1 abscissae present; $1 \mathrm{M}$ and $2 \mathrm{Cu}$ 153 not clearly delimited; 2R1 opened at apex; pterostigma short, wide in apical one-third of length;

154 hind wing with four hamuli; propodeum rectangular and not spinose; legs with slightly enlarged 155 femora. 
157 Burmapyris azevedoi sp. nov. Jouault, Perrichot \& Nel

urn:lsid:zoobank.org:act:9EE1F4FE-9B6C-43AB-8C2A-823D4A48F0E1

Holotype: Specimen identifier IGR.BU-016 (complete female, in a rectangular piece of amber measuring $5 \times 4 \times 2 \mathrm{~mm}$ ).

Etymology. The specific epithet is a patronym honoring Dr. Celso O. Azevedo, a world authority in Bethylidae taxonomy. The specific epithet is to be treat as a noun in a genitive case.

Locality and horizon. Noije Bum Hill, Hukawng Valley, Kachin State, Myanmar; upper Albian to lower Cenomanian, mid-Cretaceous.

Diagnosis. As for the genus.

Description. Female (sting slightly visible); body ca. $2.5 \mathrm{~mm}$ long, almost smooth and not strongly foveolate; wings clear and setose, LFW at least $1.50 \mathrm{~mm}$ (bent). LH $0.57 \mathrm{~mm}$; WH $0.53 \mathrm{~mm}$; WF $0.31 \mathrm{~mm}$; HE $0.18 \mathrm{~mm}$; LE ca. $0.25 \mathrm{~mm}$; OOL $0.15 \mathrm{~mm}$; WOT ca. $0.15 \mathrm{~mm}$; DAO $0.05 \mathrm{~mm}$; VOL ca. $0.12 \mathrm{~mm}$. Head slightly longer than wide, not pubescent, without dorsal median depression, sculpture apparently absent; mandible bent downward and slightly curved backwards, ca. $0.18 \mathrm{~mm}$ long; only four maxillary palpomeres visible (but certainly more numerous); flagellomeres with cylindrical cross-section; measurable antennomere lengths (in $\mathrm{mm}$ ): scape ca. $0.15 \mathrm{~mm}$, pedicel $0.08 \mathrm{~mm}, \mathrm{~F} 1$ to F7 ca. $0.12 \mathrm{~mm}, \mathrm{~F} 8$ to F10 ca. $0.11 \mathrm{~mm}, \mathrm{~F} 110.18 \mathrm{~mm}$; occipital carina conspicuous; posterior head margin curved; compound eye without microsetae, closer to mandibular insertion than to posterior head margin; ocellar triangle nearly equilateral, situated posteriorly on head, with two posterior ocelli slightly more distant from each other than from anterior.

Mesosoma with dorsum smooth, not roughly sculptured; femora slightly thickened, tibia thin, tarsal claws simple; tibial spur formula 1-2-2; arolium present; notauli well-marked, slightly posteriorly convergent; parapsidal furrows weak; metanotum developed medially and overlapping mesoscutellum posteriorly; metapectal-propodeal complex rectangular, not foveolate, with marginal carinae and no posterior spines; posterior margin of propodeum straight. Fore wing covered with mi- 
183 der not angularly incurved anterior to pterostigma; veins C, Sc+R, A, R1, Rs, Rs+M, 2r-rs\&Rs,

$184 \mathrm{M}+\mathrm{Cu}, \mathrm{M}$, cu-a and cells $\mathrm{C}, \mathrm{R}, 1 \mathrm{Cu}$, and $2 \mathrm{R} 1$ present; $\mathrm{M}$ and cu-a veins aligned; cell $2 \mathrm{Cu}$ and $1 \mathrm{M}$ 185 open, virtually enclosed by spectral vein; cell $2 \mathrm{R} 1$ distally opened; Rs+M long and prolonged as a spectral vein originating from $1 \mathrm{M}$ after pterostigma apex; pre- and post-stigmal abscissae of R1 conspicuous. Hind wing with only veins $\mathrm{C}$ and $\mathrm{Sc}+\mathrm{R}$, and 4 hamuli.

188 Metasoma with short petiole; apex interiorized, but six tergites visible, T1 reduced, T2 enlarged, all tergites convex, partly covering sternites; sting not preserved; length of clearly visible tergites: T1 $0.43 \mathrm{~mm}, \mathrm{~T} 20.27 \mathrm{~mm}, \mathrm{~T} 30.22 \mathrm{~mm}, \mathrm{~T} 4 \mathrm{ca} .0 .12 \mathrm{~mm}$, other tergites not measurable since interiorized.

194 Key to genera of $†$ Lancepyrinae (modified from Azevedo et al., 2018):

2. Fore wing with $2 \mathrm{R} 1$ cell closed Lancepyris Azevedo \& Azar, 2012 (Ain Dara am-

199 ber, Lebanon)

200 - Fore wing with 2R1 cell opened 3

201

3. Fore wing with a short pterostigma and $\mathrm{Rs}+\mathrm{M}$ vein short (not enclosing $1 \mathrm{M}$ cell or reaching apex of pterostigma) Archaepyris Evan, 1973 (Taimyr amber, Russia)

204 - Fore wing with an elongate pterostigma and Rs+M long (enclosing 1M cell or reaching apex of pterostigma) 


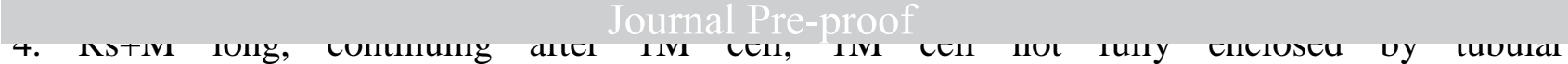

208 veins Burmapyris Jouault, Perrichot \& Nel gen. nov. (Kachin amber, My-

209 anmar)

210 - Rs+M short, only cancelling $1 \mathrm{M}$ cell, $1 \mathrm{M}$ cell fully enclosed by tubular

211 veins Protopyris Jouault \& Nel gen. nov. (Hkamti amber, My-

212 anmar)

214 5. Fore wing with cu-a vein postfurcal with $\mathrm{M}$ vein Zophepyris Engel et al.,

2152016 (Peñacerrada amber, Spain)

216 - Fore wing with cu-a vein aligned or antefurcal with M vein

6. Fore wing with $2 \mathrm{r}-\mathrm{rs} \& \mathrm{Rs}$ vein arising on distal half of pterostigma .Cretepyris Ortega-Blanco \& Engel,

2202013 (Peñacerrada amber, Spain)

221 - Fore wing with 2r-rs\&Rs vein arising on basal half of pterostigma Liztor Ortega-Blanco \& Engel, 2013 (Peñacerrada amber, Spain)

\section{Discussion}

Systematic placement and phylogenetic hypothesis

Following the key to superfamilies proposed in Goulet and Huber (1993), our specimens

228 key out in Chrysidoidea because of their pronotum being more than half as long as their mesoscu229 tum, and their metasomal terga 1 and 2 having very weak constriction at their junction dorsally and 230 laterally or with no constriction at all. Following the key to Chrysidoidea families in Goulet and 231 Huber (1993), they key out in Bethylidae because of their antenna with 10 or 11 flagellomeres, the 232 presence of wings, their profemora not enlarged or swollen, metasoma with six or seven exposed 


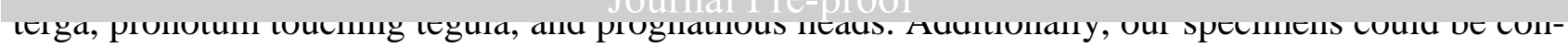

234 fused with Scolebythidae but differ from the latter in having a pronotal anterior flange rendering

235 propleura visible in dorsal aspect; the propleura closely situated so that the prostrenum is not large,

236 exposed, and diamond-shaped; and the protrochanter inserted ventrally on procoxa (Engel and Gri-

237 maldi, 2007). Our specimens also differ from $†$ Chrysobythidae at least in lacking a shallow medial

238 line on head (vs. present in $\uparrow$ Chrysobythidae); in having the clypeus more or less triangular (vs.

239 raised as a convex, somewhat squared lobe), the fore wing with a reduced number of closed cells

240 (vs. six enclosed cells) and the cells 1R1 and 2R1 open (Melo and Lucena, 2020).

Following the key to subfamily of Azevedo et al. (2018), Protopyris gen. nov. and Bur-

mapyris gen. nov. key out in †Lancepyrinae because of their developed wings; the fore wings with

Rs+M vein tubular and straight, at least as stub, with at most six closed cells; the clypeus not pro-

244 jecting backward onto frons; and the tarsal claws slightly curved. Following the key to genera of

$245 \dagger$ Lancepyrinae of Azevedo et al. (2018), Protopyris gen. nov. keys out near Archaepyris Evans,

2461973 because of the fore wing with Rs+M vein conspicuous and tubular, and 2R1 cell opened.

247 However, Protopyris gen. nov. differs from Archaepyris in having an elongate fore wing, an elon-

248 gate pterostigma, $1 \mathrm{M}$ cell conspicuous and closed, $2 \mathrm{Cu}$ cell virtually delimited by spectral veins,

249 and M and cu-a veins aligned. Unfortunately, Evans (1973) did not provide extensive illustrations

250 as for the other species he described. Thus, it is difficult to make a full comparison with our speci-

251 men. Following the key to genera of $\nmid$ Lancepyrinae of Azevedo et al. (2018), Burmapyris gen. nov.

252 also keys out near Lancepyris because of the fore wing with Rs+M vein conspicuous and tubular 253 and $2 \mathrm{R} 1$ opened, but it differs from the latter in having a fore wing with a long and wide pterostig-

254 ma, a tubular Rs+M, $1 \mathrm{M}$ and $2 \mathrm{Cu}$ cells closed by conspicuous spectral veins, $\mathrm{M}$ and cu-a veins

255 aligned, and R1 poststigmal present. Both new genera differ from each other in having the body 256 respectively depressed vs. weakly depressed, and different fore wing venations (see. Figs 257 1,2C,3,4D). 
consisting in the miniaturization, reduction of venation, enlargement of the pterostigma, and reduc-

260 tion of number of antennal flagellomeres. The reduction of wing venation has been recently investigated in two bethylid subfamilies (viz. †Holopsenellinae and Scleroderminae) by Jouault et al. (2020a), in accordance with Rasnitsyn's observations. Thereby, by comparing the age and the wing venation of the new species described herein and previously described genera, it is possible to infer some phylogenetic placement of Protopyris gen. nov. and Burmapyris gen. nov. (Fig. 5) and to propose a hypothetic phylogeny of the $\dagger$ Lancepyrinae. Lancepyris and Protopyris display a relatively more complete and complex wing venation than other representatives, with numerous closed cells. Thereby, it is likely that they diverged earlier than other lancepyrine wasps (Fig. 2C) (Azevedo et al., 2018: fig 92D). This hypothesis is also supported by their age, in fact, Lancepyris is the oldest record of the subfamily, which would be congruent with a relatively 'basal' position in the $\dagger$ Lancepyrinae. Proposing relationships between the other taxa is more complicated since the differences in venation are reduced. However, Zophepyris and Burmapyris share a tubular Rs+M vein

272 (Fig. 4D) (Azevedo et al., 2018: fig 92F), not recorded in other 'advanced' genera (viz. Liztor, Archaepyris, Cretepyris), suggesting that they could be closely related. Liztor, Archaepyris, and Cretepyris all have closed R and 1Cu cells (Azevedo et al., 2018: figs 92A,B,C,E), but only Liztor has a reduced 2r-rs\&Rs vein while Archaepyris and Cretepyris display an elongated and tubular 2rrs\&Rs vein. Thereby, we assume that these two genera could be closely related to each other than to Liztor, which could be the sister group of (Archaepyris + Cretepyris) since the rest of their wing venations is similar.

\section{Paleobiogeographic implications}


285 located near the Australian block in East Gondwana (van Hinsbergen et al., 2012; Seton et al., 2012)

286 and separated from East Laurasia (Asian region) by the Mesotethys Ocean. In addition, the extant

287 Pacific islands (Malaysia, Papua, Borneo, etc.) did not yet exist (Neall and Trewich, 2008), making

288 it almost impossible to transfer wildlife from East Laurasia to the East Gondwana (Australia and

289 Burmese Terranes). Following this period, the Burmese Terrane began to break away from the Aus-

290 tralian block to go north (as for the Indian block) to the Asian region between the Late Jurassic and

291 the Early Cretaceous (Heine et al., 2004; Heine and Müller, 2005). The Burma Terrane is supposed

292 to have been separated from the Gondwana after $125 \mathrm{Ma}$ ago, but close to its margin ca. $120 \mathrm{Ma}$

293 ago (Metcalfe, 1990, 1996; Scotese, 2014; Westerweel et al., 2019). Later, it was isolated geograph-

294 ically and occupied an island position in the Tethys Ocean between Asia and the Indian block dur-

295 ing the mid-Cretaceous (Westerweel et al., 2019) for more than 20 Ma (Heine et al., 2004; Seton et

296 al., 2012). It is very likely that the stem group of the Bethylidae was already present on the Burma

297 Terrane before its complete separation from Gondwana, ca. 125-120 Ma ago, since we already have

298 fossil record of the family in Lebanese amber during the Barremian (Fig. 6) (Azevedo and Azar,

299 2012). The record of lancepyrine wasps in Lebanese and Spanish amber (in southern Laurasia), re-

300 spectively located in the central part of the southern Tethyan margin and the western Tethyan mar-

301 gin (Peris et al., 2016: fig. 1), suggests that the $†$ Lancepyrinae were already diversified along the

302 western Tethys. However, the record of Protopyris gen. nov. and Burmapyris gen. nov. on the

303 Burma Terrane suggests that the $\dagger$ Lancepyrinae had also conquered the eastern Gondwana before

304 the break-up of the Burma Terrane. Ezcurra and Agnolin (2012: fig. 2) proposed the paleogeograph-

305 ic Eurogondwana model, according to which Gondwanan lineages could colonize Laurasia and

306 North America via an Apulia microplate from 145 to $99 \mathrm{Ma}$, prior to continental drift. This scenario

307 is in accordance with the presence of other †Lancepyrinae in Spain and Lebanon during the Early

308 Cretaceous (Azevedo and Azar, 2012; Ortega-Blanco and Engel, 2013; Engel et al., 2016). The rec-

309 ord of Archaepyris in Taimyr amber (Late Cretaceous) (Evans, 1973) may also indicate that the 
311 peculiar geological history, it is very likely that the $\dagger$ Lancepyrinae and, therefore the Bethylidae,

312 arose before the break-up of the Burma Terrane from South-East Gondwana, indicating at least an

313 Early Cretaceous (or even Late Jurassic) origin for the family.

\section{Conclusion}

316 Both new genera described herein are the first $\dagger$ Lancepyrinae described from Burmese amber and

317 Protopyris myanmarensis gen. et sp. nov. is the first Bethylidae described from the lower Albian

318 Hkamti amber. These discoveries highlight the underestimated diversity of bethylid wasps in Bur-

319 mese biota. The peculiar palaeogeographic history of the Burma Terrane provides evidence for the 320 antiquity of the $\dagger$ Lancepyrinae and, therefore, of the entire Bethylidae family. It is likely that the 321 Bethylidae arose during the earliest Cretaceous, before the Gondwana breakup, and maybe during 322 the Late Jurassic. It stands to reason that a morphological- and molecular-based phylogeny with 323 time divergence estimates has becomes a necessity for our understanding of this family.

\section{Acknowledgment}

326 We sincerely thank Pr. Alexandr. P. Rasnitsyn, an anonymous referee, and editor Dr. Eduardo

327 Koutsoukos for their very helpful remarks on the first version of the paper.

References

Azevedo, C.O., Alencar, I.D.C.C., Ramos, M.S., Barbosa, D.N., Colombo, W.D., Vargas, J.M.R., Lim, J., 2018. Global guide of the flat wasps (Hymenoptera, Bethylidae). Zootaxa 4489, 1-294.

333 Azevedo, C.O., Azar, D., 2012. A new fossil subfamily of Bethylidae (Hymenoptera) from the Ear334 ly Cretaceous Lebanese amber and its phylogenetic position. Zoologia 29, 210-218. 335 https://doi.org/10.1590/S1984-46702012000300004 
337 idae) inferred from 28S and 16S rRNA genes. Insect Systematics and Evolution 41, 55-73. $338 \quad$ https://doi.org/10.1163/187631210X486995

339 Colombo, W.D., Perkovsky, E.E., Azevedo. C.O., 2020. Phylogenetic overview of flat wasps (Hy340 menoptera, Bethylidae) reveals Elektroepyrinae, a new fossil subfamily. Palaeoentomology 3, 341 269-283. https://doi.org/10.11646/palaeoentomology.3.3.8

342 Cruickshank, R.D., Ko, K., 2003. Geology of an amber locality in the Hukawng Valley, northern 343 Myanmar. Journal of Asian Earth Sciences 21, 441-455. https://doi.org/10.1016/S1367$3449120(02) 00044-5$

345 Engel, M.S., Grimaldi, D.A., 2007. Cretaceous Scolebythidae and phylogeny of the family (Hymenoptera: Chrysidoidea). American Museum Novitates 3568, $\quad 1-16$. http://hdl.handle.net/2246/5859

348 Engel, M.S., Ortega-Blanco, J., Azevedo, C.O., 2016. A new bethylid wasp in Lebanese Early Cre349 taceous amber (Hymenoptera: Chrysidoidea), with comments on other Mesozoic taxa. American 350 Museum Novitates 3855, 1-14. https://doi.org/10.5962/bhl.title.156715

351 Evans, H.E., 1973. Cretaceous aculeate wasps from Taimyr, Siberia (Hymenoptera). Psyche 80, 166-178. https://doi.org/10.1155/1973/16876

353 Ezcurra, M.D., Agnolin, F.L., 2012. A new global palaeobiogeographical model for the Late Mesozoic and Early Tertiary. Systematic Biology 61, 553-566. https://doi.org/10.1093/sysbio/syr115

Goulet, H., Huber, J.T., 1993. Hymenoptera of the world: An identification guide to families. ed. Agriculture Canada, Ottawa, Ontario, 680 pp.

Grimaldi, D., Ross, A., 2017. Extraordinary lagerstätten in amber, with particular reference to the 358 Cretaceous of Burma. In: Fraser, N.C., Sues, H.-D., (Eds.), Terrestrial conservation lagerstätten: 359 Windows into the evolution of life on land. Dunedin Academic Press, Edinburgh: 287-342.

360 Harris, R.A., 1979. The glossary of surface sculpturing. Occasional Papers in Entomology Califor361 nia Department of Food and Agriculture Laboratory Services Supplement 28, 1-31. 
363 geometry and spreading ridge configuration. Australian Journal of Earth Sciences 52, 27-39.

$364 \quad$ https://doi.org/10.1080/08120090500100077

365 Heine, C., Müller, R.D., Gaina, C., 2004. Reconstructing the lost eastern Tethys ocean basin: con366 vergence history of the SE Asian margin and marine gateways. Geophysical Monograph Series 367 149, 1-18. https://doi.org/10.1029/149GM03

368 van Hinsbergen, D.J.J., Lippert, P.C., Dupont-Nivet, G., McQuarrie, N., Doubrovine, P.V., 369 Spakman, W., Torsvik, T.H., 2012. Greater India Basin hypothesis and a two-stage Cenozoic 370 collision between India and Asia. Proceedings of the National Academy of Sciences of the Unit371 ed States of America 109, 7659-7664. https://doi.org/10.1073/pnas.1117262109

372 Jouault, C., Ngô-Muller, V., Pouillon, J.-M., Nel, A., 2020a. New Burmese amber fossils clarify the 373 evolution of bethylid wasps (Hymenoptera: Chrysidoidea). Zoological Journal of the Linnean 374 Society zlaa078. https://doi.org/10.1093/zoolinnean/zlaa078

375 Jouault, C., Perrichot, V., Nel, A., 2020b. A new genus and species of parasitic wasps (Hymenop376 tera: Diapriidae) from Hkamti 'mid-Cretaceous' Burmese amber. Cretaceous Research 104533. 377 https://doi.org/10.1016/j.cretres.2020.104533

378 Melo, G.A.R., Lucena, D.A.A., 2020. †Chrysobythidae, a new family of chrysidoid wasps from 379 Cretaceous Burmese amber (Hymenoptera, Aculeata). Historical Biology 32, 1143-1155. $380 \quad$ https://doi.org/10.1080/08912963.2019.1570184

381 Metcalfe, I., 1990. Allochthonous terrane processes in Southeast Asia. Philosophical Transactions 382 of the Royal Society of London A331, 625-640. https://doi.org/10.1098/rsta.1990.0094

383 Metcalfe, I., 1996. Pre-Cretaceous evolution of SE Asian terranes. In: Hall, R., Blundell, D. (Eds). 384 Tectonic evolution of Southeast Asia. Geological Society Special Publication 106, 97-122. 385 https://doi.org/10.1144/GSL.SP.1996.106.01.09 
387 Philos Transactions of the Royal Society of London (B Biological Sciences) 363, 3293-3308.

$388 \quad$ https://doi.org/10.1098/rstb.2008.0119

389 Ortega-Blanco, J., Engel, M.S., 2013. Bethylidae from Early Cretaceous Spanish amber (Hymenop390 tera: Chrysidoidea). Journal of the Kansas Entomological Society 86, 264-276. $391 \quad$ https://doi.org/10.2317/JKES130312.1

392 Peris, D., Ruzzier, E., Perrichot, V., Delclòs, X., 2016. Evolutionary and paleobiological implica393 tions of Coleoptera (Insecta) from Tethyan-influenced Cretaceous ambers. Geoscience Frontiers 7, 695-706. http://dx.doi.org/10.1016/j.gsf.2015.12.007

Rasnitsyn, A.P., 1969. The origin and evolution of Lower Hymenoptera. Transactions of the Paleontological Institute, Academy of Sciences of the USSR 123, 1-196 [In Russian].

Rasnitsyn, A.P., 1980. [Origin and evolution of Hymenoptera]. Transactions of the Paleontological Institute, Academy of Sciences of the USSR 174, 1-192 [in Russian].

Scotese, C.R. 2014. Atlas of Early Cretaceous Paleogeographic Maps, PALEOMAP Atlas for ArcGIS, volume 2, The Cretaceous, Maps 23-31, Mollweide Projection, PALEOMAP Project, Evanston, IL.

402 Seton, M., Müller, R.D., Zahirovic, S., Gaina, C., Torsvik, T., Shepard, G., Talsma, A., Gurnis, M., 403 Turner, M., Maus, S., Chandler, M., 2012. Global continental and ocean basin reconstructions 404 since $200 \quad$ Ma. 270 Review 405 https://doi.org/10.1016/j.earscirev.2012.03.002

406 Shi, G.H., Grimaldi, D.A., Harlow, G.E., Wang, J., Wang, J., Yang, M.C., Lei, W.Y., Li, Q.L., Li, 407 X.H., 2012. Age constraint on Burmese amber based on U-Pb dating of zircons. Cretaceous Re408 search 37, 155-163. https://doi.org/10.1016/j.cretres.2012.03.014

409 Westerweel, J., Roperch, P., Licht, A., Dupont-Nivet, G., Win, Z., Poblete, F., Ruffet, G., Swe, 410 H.H., Thi, M.K., Aung, D.W., 2019. Burma Terrane part of the Trans-Tethyan arc during colli- 


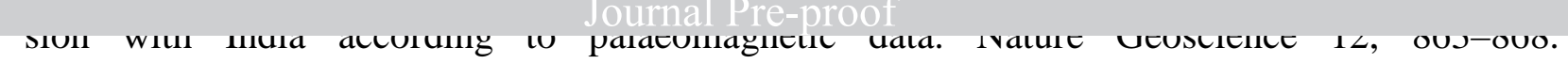

413 Xing, L., Qiu, L., 2020. Zircon U-Pb age constraints on the mid-Cretaceous Hkamti amber biota in

414 northern Myanmar. Palaeogeography, Palaeoclimatology, Palaeoecology 558, 109960.

415 https://doi.org/10.1016/j.palaeo.2020.109960

416 Xing, L., Sames, B., McKellar, R.C., Xi, D., Bai, M., Wan, X., 2018. A gigantic marine ostracod

417 (Crustacea: Myodocopa) trapped in mid-Cretaceous Burmese amber. Scientific Reports 8, 1365.

418 https://doi.org/10.1038/s41598-018-19877-y

419 Yu, T., Kelly, R., Mu, L., Ross, A., Kennedy, J., Broly, P., Xia, F., Zhang, H., Wang, B., Dilcher, 420 D., 2019. An ammonite trapped in Burmese amber. Proceedings of the National Academy of 421 Sciences of the USA 116, 11345-11350. https://doi.org/10.1073/pnas.1821292116

422 Zheng, D., Chang, S., Perrichot, V. et al. 2018. A Late Cretaceous amber biota from central Myan-

423 mar. Nature Communications 9, 3170. https://doi.org/10.1038/s41467-018-05650-2

425 Figure captions.

427 Figure 1. Protopyris myanmarensis sp. nov. Jouault \& Nel, holotype IGR.BU-015. Photographs of 428 habitus. A: Dorsal view. B: Ventral view. Scale bars: $0.5 \mathrm{~mm}$.

430 Figure 2. Protopyris myanmarensis sp. nov. Jouault \& Nel, holotype IGR.BU-015. A: Mesosoma. 431 B: Head. C: Wing. D: Line drawing of fore wing with vein and cell nomenclature (cell names in 432 bold). Scale bars: $0.25 \mathrm{~mm}(\mathrm{~A}, \mathrm{~B}) ; 0.5 \mathrm{~mm}(\mathrm{C})$.

434 Figure 3. Burmapyris azevedoi sp. nov. Jouault, Perrichot \& Nel, holotype IGR.BU-016. Photo435 graphs of habitus A: Right view. B: Left view. Scale bars: $0.5 \mathrm{~mm}$. 
438 in left view. B: Mesosoma. C: Wings (with hamuli indicated by black arrows). D: Line drawing

439 of fore wing with vein and cell nomenclature (cell names in bold). Scale bars: $0.25 \mathrm{~mm}$.

440

441 Figure 5. Hypothetical phylogeny of Lancepyrinae with affixed geological time scale.

443 Figure 6. Global paleogeographic reconstruction for the mid-Cretaceous (100 Ma) period, showing 444 distribution of Lancepyrinae; modified from Global Paleogeography and Tectonics in Deep Time 445 (C) 2016 Colorado Plateau Geosystems Inc., localities of amber-producing forests after Wester$446 \quad$ weel et al. (2019). 
The authors declare that they have no known competing financial interests or personal relationships that could have appeared to influence the work reported in this paper. 